\title{
Biography, science studies and the historiography of archaeological research: Managing personal archives
}

\author{
Biografia, estudios sobre la ciencia y la escritura de la historia de la \\ investigacion arqueologica: \\ trabajando con archivos personales
}

\author{
Marc Antoine KAESER \\ Director of the Latenium, Archaeology Park and Museum, Neuchatel (Switzerland) \\ Associate Professor, Institute of Archaeology, Neuchatel University \\ Latenium, Espace Paul-Vouga, CH-2068 Hauterive \\ marc-antoine.kaeser@unine.ch
}

Recibido:10-02-2013

Aceptado:24-06-2013

\begin{abstract}
This paper examines the potential of biographical studies for the history of archaeology. In particular, I seek to demonstrate that personal archives may be a valuable source for the historiography of archaeological research. First, they allow the identification of practical interactions between science and society. Second, personal archives allow us to underscore the epistemological interference between the discussion of archaeological topics and certain scientific debates, which has traditionally been overlooked by historians of archaeology. Third, I argue that biography and the use of personal archives may well contribute to reconciliation between critical approaches inspired by science studies and the more traditional history of ideas. Simultaneously, they compel historians of archaeology to broaden their perspectives to the history of science in general in order to consider the origins of the present discipline in the context of past configurations of knowledge and research.
\end{abstract}

Key words: Biography. Personal Archives. History of Archaeology. History of Science. Disciplinarization.

\begin{abstract}
RESUMEN
Este articulo examina el potencial de los estudios biográficos para la historia de la arqueología. Mi objetivo es demostrar que los archivos personales constituyen una valiosa fuente para la historia de la investigación arqueológica. En primer lugar, dichos archivos permiten identificar interacciones prácticas entre ciencia y sociedad. En segundo lugar, en un nivel puramente cognitivo, dichos archivos permiten abordar la interferencia epistemológica entre ciertas discusiones arqueológicas y algunos debates cientificos que han sido tradicionalmente ignorados por los historiadores de la arqueología. En tercer lugar, considero que la biografía y el análisis de archivos personales puede contribuir a la reconciliación entre una serie de análisis críticos inspirados en los Sciences studies y enfoques más tradicionales inspirados en la historia de las ideas. Además, los estudios biográficos permiten al historiador de la arqueología incorporar sus perspectivas a la historia de la ciencia y, de este modo, considerar los orígenes de la presente disciplina en el contexto de la configuración pasada del conocimiento y de la investigación.
\end{abstract}

Palabras clave: Biografia. Archivos privados. Historia de la arqueología. Historia de la ciencia. Estudios disciplinares. 


\section{Historical biography: A strong comeback}

In the field of historical research, for over a decade now, one can observe a strong comeback of biography. This trend, which takes on spectacular proportions in the Anglo-American editorial landscape, is certainly connected with the present theoretical disarray within the discipline of history (Noiriel 1996; Hunt \& Bonnel 1999; Kalb \& Tak 2005). Considering the «paradigm crisis» (Noiriel 1996: 123-171), some historians may gladly succumb to (and take advantage of) the obvious seduction of the biographical genre. Even so, this comeback cannot be reduced to such merely opportunistic motives; biography's comeback is also indisputably qualitative (Kaeser 2003). After a long period of discredit, during which it was confined to the register of amateur or popular history, biography has now clearly achieved academic recognition and scientific legitimacy. Firmly grounded on new theoretical and methodological foundations (Levi 1989; Lepetit 1995; Loriga 1996), biographical studies have proven their heuristic worth within many debates and problems to be solved today in the field of history.

In the historiography of science, this comeback may seem quite worrisome. The canons of the conventional, lenient hagiographies of scientists can be traced back to the ritual éloges (praises) of the French Académie des Sciences as early as the beginning of the $18^{\text {th }}$ century. Later on, the Victorian biographies of scientists (those heroes of knowledge celebrated in best-sellers such as Bolton 1889 or Lodge 1893) played a central role in the affirmation of the biographical genre in literary history (Shortland \& Yeo 1996), a genre that remained quite popular during the first half of the $20^{\text {th }}$ century (Gibson 1913; Grove 1929; Lenard 1933). Only the development of the philosophy of science, with the structuralist 'death of the author', could eventually discredit the obviously indulgent 'life and works' and the portraits of retrospective 'disciplinary fathers' (Blanckaert 1999).

Now such worrying actually appears out of place. The return of biography to the history of science definitely has nothing to do with a comeback of such simplistic and apologetic perspectives. Quite to the contrary, this comeback (and its legitimization), which evolved within social history ${ }^{1}$ and the sociology of science as early as the 1970s (Shapin \& Thackray 1974; Hankins 1979), has built upon renewed historiographic foundations (e. g. Blanckaert 1988; Roger 1995).

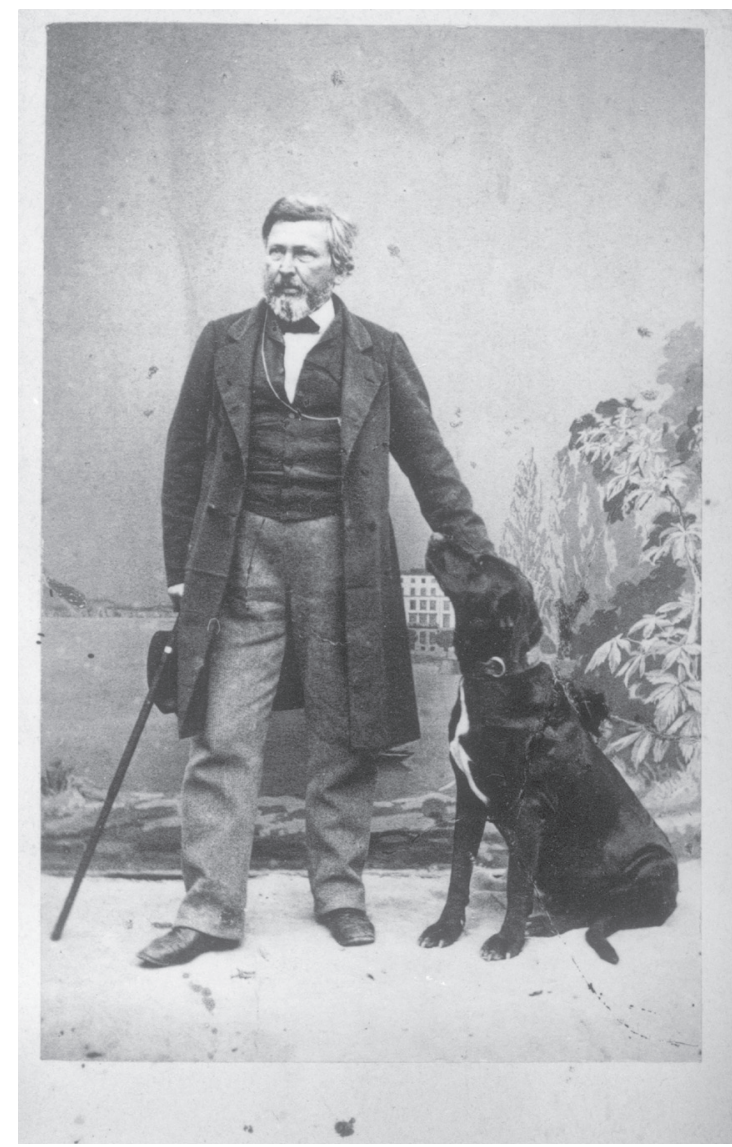

Figure 1. Edouard Desor (1811-1882), with his dog Rino. Bibliothèque publique et universitaire, Neuchâtel.

\section{Sources for archaeological biographies}

Whatever the motives, the biography trend is expanding within the historiography of archaeology (Murray 1999), and it will certainly continue to do so. We are thus bound to reflect on the role of biography in the reconstruction of archaeology's past. In this respect, the sources of biographies deserve special attention as they cast light on some aspects that are difficult to deal with otherwise.

Schematically, three main categories of sources can be distinguished that are specifically relevant for the biographies of archaeologists: oral sources ${ }^{2}$, material sources ${ }^{3}$ and private papers. Since the first two categories are already dealt with in this volume, I will focus here on private papers. This focus is based on the book I dedicated to the figure of the $19^{\text {th }}$ century Germano-Swiss prehistorian, Edouard Desor (figure 1; Kaeser 2004), which provides a 
biographical study that relies upon a large body of such documentation - ca. 30'000 letters, some 75 notebooks of a personal diary, and thousands of separate, private documents (intimate, scientific, political, as well as business papers). The large scope of activities and engagements of this scientist - who was simultaneously a geologist, a palaeontologist and an archaeologist, as well as a businessman, a politician and a religious reformer - allowed us to engage into the theoretical and methodological definition of a microhistorical biography (Kaeser 2008).

\section{The diversity of personal archives}

The personal archives of scientists are characterized by a great diversity both in their form and their content. Formally, they can be divided into the following types of papers.

1. Correspondences: as a general rule, this is the best-preserved and quantitatively most important category of private papers and may luckily include outgoing and incoming letters. When such documents are available, the biographer should take into consideration not only letters that can be labeled as properly scien- tific, but also (as far as possible) purely private exchanges, which can be very useful as well.

2. Separate scientific notes, drafts, lectures, conferences and publication proofs: since such documents are quite easy to compare with the actual publications, they are particularly valuable for the epistemological analysis of the history of science.

3. Thematic files of all kinds (e.g. reading notes, flyers, meeting minutes and membership lists): in this case (as will be shown later), the reconstruction of the history of archival classification may prove decisive. Does the thematic filing and organization go back to the lifetime of the subject himself?

4. Personal diaries: although they offer a clear benefit for every biographer, these diaries require special attention. It should be noted that even if they do not include scientific thoughts and reflections, such documents can be very useful to the historian of science, since even the most mundane diary reveals at least what the subject thought useful to remember. And in the case of Desor's diary(figure 2), the mere mention of a severe cold he suffered from while attending a congress helped us to understand the poor impact of a speech whose publication appears quite convincing a posteriori.

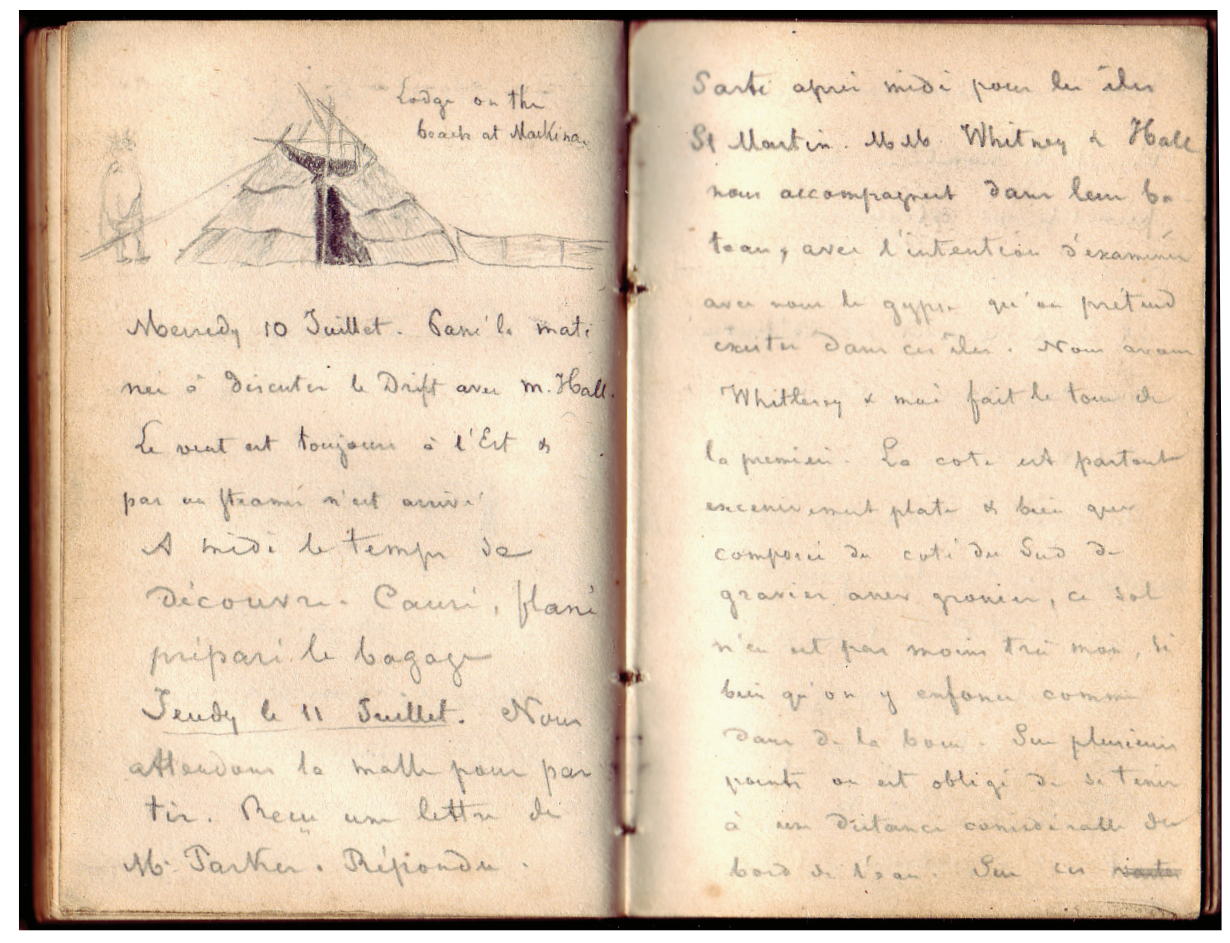

Figure 2. Edouard Desor's private diary, 10th-11th July 1850: geological survey of the Michigan Peninsula. Bibliothèque publique et universitaire, Neuchâtel. 
5. Private libraries: this category offers unique insights into the subject's personal taste and frame of knowledge. Private libraries can be preserved as a whole (hopefully) or reconstituted with the help of various clues (e.g. catalogues, ex libris or specific bindings). They allow the biographer to compare the readings explicitly referred to in the publications of their subject with the subject's actual readings (or rather, with the published sources in his or her possession). This comparison may well show that inspirations were actually drawn from sources that did not appear adequate or worth citing, whereas some "compulsory" references might not have been read at all. Isolated books or pamphlets can also be useful, provided they contain manuscript annotations of some kind ${ }^{4}$.

\section{Methodological assets: A multiplicity of possible cross-checking in source criticism}

When dealing with archival sources, the biographer needs to take some precautions. Due to the «reality effect» characterized by Arlette Farge (1989), the materiality of the document and the immediacy of its message can indeed mislead the historian to selfindulgent, lenient interpretations. In this respect, personal archives require special precautions since this reality effect is clearly increased by the risk of biographers identifying with their subject (Shortland \& Yeo 1996: 31 sqq.) or the appropriation by biographers of their subject, a risk which is even greater if the biographers of archaeologists are archaeologists themselves. What should be stressed in regards to this risk is the importance of source criticism, both internal ${ }^{5}$ (textual logic and consistency) and external (conditions of production of the document). On this methodological level, the abovementioned formal diversity of personal archives forms a major asset in the implementation of source criticism; it allows the biographer to multiply the necessary cross-checks.

This cross-checking can be applied first within the different archival units - by confronting, for instance, different elements of the correspondences. Here the biographer can compare all the letters of the subject of the biography (A) to various addressees ( $\mathrm{B}, \mathrm{C}$ and so on) during a particular period of time and on a particular topic. The biographer may extend the research to other private correspondences if necessary (and available), relying on letters exchanged between different addressees (B to C, C to $B$ ) at the same period of time, where $B$ and $C$ refer to the mail received from $\mathrm{A}$ and express reactions, opinions or feelings about this mail. Second, such double cross-checking (a kind of triangulation) can be extended to other categories of archival units. For instance, the biographer can move from the correspondences to the subject's personal diaries, looking for any mention of the writing or topics of these letters. It may happen that the personal diaries of some of the addressees have been preserved, which allows the biographer to compare the subjective accounts of the different correspondents involved.

In short, the personal archives and the limited scope of the biography allow the historian to multiply the documentary angles and approach the past in a true three-dimensional perspective, where the protagonists, their ideas and their deeds can be understood in a relatively realistic depth, thus counterbalancing the flattening-off of historic reconstruction.

\section{Grasping the development of scientific concepts}

I have tried to show elsewhere the overall relevance of biography for the study of science from a microhistorical perspective of an historiographical reconstruction of «science in action» (Latour $1987)$ or rather, «real-life science» (Kaeser 2003). If we consider biography from the perspective of the traditional history of ideas, it would seem that personal archives of any kind do not come in very handy. In scientific matters, documents such as letters, drafts or private diaries are rather allusive or even confusing; this makes them poor guides for the historian of ideas, who focuses on the analysis of published works. When scientific undertakings are considered as a process, however, such documents may prove exceptionally useful for the history of science. Personalar chives allow us to study and to understand the forming of ideas. Such documents allow us to reconstruct a fuller context - to go, so to say, from the dining room of science to the kitchen where the dishes have been cooked (and need to be washed). To further the metaphor, private papers allow historians to look for the various ingredients of the meals that have been prepared for the reader of the original scientific publications.

Most scientists would surely acknowledge that the rhetorical development of their published argumentation does not follow the same line of thought as when they first analyzed the topic. Consciously or not, scientific authors will often conceal or ignore some of their actual inspirations; for the sake of demonstration, the connections are drawn with more convincing references or those deemed more appropriate for the audience that is being addressed. In contrast, the study of personal archives allows historians to reconstruct the process of science and the development of concepts that appear only as 
end products in the publications. From a reflexive perspective, when archaeologists study the history of research in order to enhance their understanding of the weaknesses and sometimes hidden implications of archaeological knowledge still shared today within the scientific community, such evidence is obviously of great value. In other words, the insights driven from the exploration of personal archives are particularly helpful for a critical, presentist use of the history of the discipline.

\section{Broadening the scope of inquiry in the history of archaeology}

As for the implementation of source criticism and the understanding of a three-dimensional past, the relevance of the formal diversity of personal archives and of cross-checking all of these different source units has already been underlined above. The same applies to the thematic diversity of private papers: these personal archives allow the biographer to grasp the historical relations between science and society.

It is hard to deny the infinite complexity and tremendous richness of the past. In order to deal with this complexity and richness, historians are naturally bound to restrict their sphere of inquiry; their focus must adapt to specific frames, problems, questions and angles, which may be, for example, thematic, archival, chronological or geographical. While such restrictions make sense in the historiographic context of scientific research, they usually respect consistent and conventional limits, which often do not fit with any objective outline of historic reality.

In this regard, biographers are in a much more comfortable position. Their historiographic restrictions follow an outline that is objective in its essence - the life (and the imaginary world) of a real historic person. Under these circumstances, they can concentrate on an extremely narrow portion of the past; starting from that portion, their viewpoints open to the great variety of topics that have affected the subject of their biography. Based on the evidence in the private archives, the biographers are ideally placed to restore the actual historic connections among all those different topics, connections that they can understand better by using all the clues given to them through their familiarity with the individual subject.

The uniqueness of a biography (and the use of private archives) lies precisely in the possibility to easily bundle a great variety of topics without the risk of anachronism. While focusing on a single individual, the biographer can take note of, docu- ment and analyze connections amongst topics or events that may initially appear to be completely independent. Such connections appear in a particularly striking way when the biographer tackles the development of concepts. Here, private archives offer an invaluable key to sometimes surprising connections, inferences or inspirations, between the life and experience of the subject on the one hand, and his or her scientific works on the other.

My biography of Desor provides countless examples of historic interferences between thematics that presently bear no connection at all. It is impossible, for instance, to understand Desor's publications on Egyptian flints or those on Siberian grave finds without realizing, even if this is never explicitly referred to in these archaeological works, that the debates about the Egyptian Neolithic or the Russian Bronze Age were instrumental in another discussion - the major anthropological debate on monogenism versus polygenism (i.e., the unique or plural origin of mankind). Desor's private papers offer us a clue to these implicit connections, which were certainly obvious to every late $19^{\text {th }}$ century reader of these archaeological publications. Similarly, the study of his personal archives shows that Desor's questioning of the well-established interpretation of the famous Celtic site of La Tène as a habitat(Kaeser 2013) was only a pretext to sustain an evolutionist theory on the alleged functional development of lake-dwellings, which would have it that these sites progressively evolved from permanent villages (Stone Age) to occasional meeting places (Bronze Age) to warehouses (Iron Age).

Moreover, it is quite evident that archaeological ideas and concepts are constantly influenced by current events in politics and economics, and by the religious beliefs, personal experiences and particular events in the life of the archaeologist under study ${ }^{6}$. In a rather subtler way, the biography of an archaeologist demonstrates how archaeological methods, theories, interpretations and discussions have been influenced by research and debates in other sciences (and conversely, how the former has an impact on the latter). For obvious reasons, such influence from other fields of research was particularly frequent and effective when archaeology had not yet reached disciplinary status (Kaeser 2006). Now, these influences are often difficult or even impossible to detect in archaeological publications; they were tacit or even unconscious. Because of these difficulties, the biographer's identification of such influences in private archives can therefore have considerable importance for the history of archaeology.

This permeability clearly demonstrates the inadequacy of a strictly disciplinary, internalist history of archaeology (Moro Abadia 2007). The origins 
and the development of archaeology cannot be understood separately from developments in other sciences, nor can they be understood merely with reference to the explicit connections called upon in archaeological publications. In light of this, biography can teach the historian of archaeology to transform him- or herself into a true historian of science.

\section{Science studies into archaeology's past: From theory to practice}

Considering the development in social studies of science, the connections highlighted above will not come as a surprise. To the sociologist of science, the role of such connections in the construction of knowledge is patently obvious. Contrary to the connections that the sociologist's deconstruction usually calls upon, however, the interferences and conjunctions brought to the fore by the biographer allow a decisive shift from theory and interpretation to practice and demonstration. The biographer has the opportunity to confirm, prove and detail connections that have left visible traces in the private archives, even when the subject of the biography himself appears unaware of his or her own influences.

For example, the biographer might look in the archives for the first formulation of a concept or a theory later developed by the subject and find it in the draft of a public lecture. Examining the corre- spondence around that date, he or she might then assess the significance given to the topic by the subject. Finally, turning to the personal diary of the subject in the previous days, weeks or months, the biographer might discover the immediate cause of the first inspiration. My biographical study of Desor (Kaeser 2004) illustrates numerous such unexpected, unavowed and often unconscious connections, which were driven from a conversation reported in a diary, a sermon heard at church, the mention of a political event that left an impression, the allusion to a museum visit, the reading of an ethnographical report or even a novel. In other words, while gaining an advantage from cross-checking the various elements of private archives, biographers are able to identify the motives that trigger scientific ideas. They can reconstruct the thought processes at stake, as well as the actual steps of establishing scientific argumentation.

In conclusion, making use of private archives is certainly the most practical way to grasp the social context independently of presentist categories and to free the historiography of science from social determinism. Moreover, according to the constructivist principles of the actor-network theory (Latour $1987 ; 2005)$, the use of private archives allows the historian to restore the dynamic and elastic qualities of the context, for the 'context' only exists through interactions between subjective perceptions of historical actors - subjective perceptions to which private archives offer the best possible access.

\section{ACKNowledgements}

The author wishes to thank Oscar Moro, Dietrich Hakelberg, Amelia M. Pope, Jeannette Regan and the anonymous reviewers for their useful comments, corrections and proofreading of a first draft of this paper.

\section{Notes}

1. Considering Bourdieu's fierce condemnation of the «biographical illusion» (Bourdieu 1986), this interest for individual life-paths among sociologists may seem rather surprising. Actually, it appears that it was based on misleading pretensions of 'representativity' (Söderqvist 1996: 47ff.; Kaeser 2003).

2. It is worth noting here that oral sources can also be relevant for the biography of scientists who died long ago, when the biographer chooses to encompass not only the history, but also the memory of the subject. In a reflexive perspective, the discrepancy between history and memory reveals information about the reception and actual impact of his or her scientific contributions.

3. Considering the relevance of archaeological collections from a biographical perspective, all the evidence (written and material) related to the scientific treatment of these artifacts should be examined. Such evidence is of cardinal importance for reconstituting the practices of collection (selection and classification, formal and material analysis, conservation and restoration, interpretation and reconstitution, and storage and exhibition, among others).

4. Some very special cases may provide quite unpredictable information. Going through the shelves of the library in Desor's former summer estate, I found a copy of Herodotes' Histories, which had obviously belonged to the 19th-century scientist. This was an interesting discovery, for the reference to 'Herodotes, Terpsichore XVI, 5' 
played an important part in $19^{\text {th }}$ century interpretations of prehistoric lake-dwellings. This reference, however, usually appeared to be taken out of its context and it was assumed that it relied only on secondhand knowledge. The actual presence of the book in Desor's library seems to back up the hypothesis that Herodotes had been deliberately inadequately quoted. Although the book did not contain any annotations, the thick, 600-page volume actually opened directly at the right page. This provides invisible evidence, yet sustainable proof, that Desor did concentrate his reading on this particular passage.

5. In this respect, the biographer should be helped by his intimate knowledge of the subject's psychology. For instance, the occurrence of different handwritings, each characteristic of different moods or levels of expression, may be a good clue for the assessment of the various circumstantial forms of credibility of some manuscript assertions.

6. Such influences belong to a dynamic that works equally well conversely (Levi 1989): archaeologists' personal lives depend upon their work and career; their understanding of their own «private world» (Chartier 1989) is clearly influenced by their intellectual concerns and questionings (Kaeser 2004).

\section{BibliographiCAL REFERENCES}

Blanckaert, C. (1988): 'Story' et 'history’ de l'ethnologie. Revue de synthèse, 109/3-4: 451-467.

BlancKaert, C. (1999): L'histoire générale des sciences de l'homme: Principes et périodisation. L'histoire des sciences de l'homme. Trajectoire, enjeux et questions vives. (C. Blanckaert, ed.), L'Harmattan, Paris: 23-60.

Bolton, S. K. (1889): Famous men of science. Hodder and Stoughton, London.

Bourdieu, P. (1986): L'illusion biographique. Actes de la recherche en sciences sociales, 62/63: 69-72.

Chartier, R. (1989): Le monde comme représentation. Annales E.S.C., 6: 1505-1520.

FARge, A. (1989): Le goût de l'archive. Le Seuil, Paris.

GiBson, C. R. (1913): Heroes of science: an account of the lives, sacrifices, successes, and failures of some of the greatest scientists in the world's history. Lippincott, Philadelphia.

Grove, W. (1929): Great men of science. Their lives and discoveries. The New Home Library, New York.

HANKIns, T. L. (1979): In defence of biography: The use of biography in the history of science. History of science, 17: 1-16.

Hunt, L.; Bonnel, V. (1999): Beyond the Cultural Turn (L. Hunt \& V. Bonnel, eds.). University of California Press, Berkeley.

KAESER, M.-A. (2003): La science vécue. Les potentialités de la biographie en histoire des sciences. Revue d'Histoire des Sciences Humaines, 8: 139-160.

KAESER, M.-A. (2004): L'univers du préhistorien. Science, foi et politique dans l'œuvre et la vie d'Edouard Desor (1811-1882). L'Harmattan, Paris.

KaEser, M.-A. (2006): The First Establishment of Prehistoric Science. The Shortcomings of Autonomy. Die Anfänge der ur- und frühgeschichtlichen Archäologie als archäologisches Fach (1890-1930) im europäischen Vergleich (J. Callmer \& al. eds.), M. Leidorf, Rahden: 149-160.

KAESER, M.-A. (2008): Biography as Microhistory. The Relevance of Private Archives for Writing of the History of Archaeology. Archives, Ancestors, Practices. Archaeology in the Light of its History (N. Schlanger, J. Nordbladh, eds.), Berghahn Books, Oxford: 9-20.

KAESER, M.-A. (2013): Les interprétations du site de La Tène: des interférences et des parasitages significatifs. Les armes dans les eaux: Questions d'interprétation en archéologie (A. Testart dir.), Errance, Paris: 53-72.

Kalb, D.; TAK, H. (ed.) (2005): Critical Junctions. Anthropology and History beyond the Cultural Turn. Berghahn Books, New York.

Latour, B. (1987): Science in Action: How to follow scientists and engineers. Harvard University Press, Cambridge/Mass.

Latour, B. (2005): Reassembling the Social: An Introduction to Actor-Network-Theory. Oxford University Press, Oxford.

LENARD, P. (1933): Great men of science: a history of scientific progress. Bell, London.

LePetit, B. (1995): L'histoire prend-elle les acteurs au sérieux? Espaces-Temps, 59-60-61: 112-122.

LeVI, G. (1989): Les usages de la biographie. Annales E.S.C., 6: 1325-1336. 
Lodge, O. (1893): Pionniers of science and the development of their scientific theories. Macmillan \& Co., London.

Loriga S. (1996): La biographie comme problème. Jeux d'échelles. La micro-analyse à l'expérience (J. Revel, ed.), EHESS-Gallimard-Seuil, Paris: 209-231.

Moro Abadía, O. (2007): Arqueología Prehistórica e Historia de la ciencia: Hacia una historia crítica de la arqueología. Bellaterra, Barcelona.

Murray, T. (1999): Epilogue: The Art of Archaeological Biography. Encyclopedia of Archaeology, The Great Archaeologists (T. Murray ed.). ABC-Clio, Santa Barbara: 869-883.

NoIriel, G. (1996): Sur la “crise” de l'histoire. Belin, Paris.

Roger, J. (1995): Pour une histoire des sciences à part entière. Albin Michel, Paris.

Shapin, S.; Thackray, A. (1974): Prosopography as a research tool in history of science: The British scientific community (1700-1900). History of science, 12: 1-28.

Shortland, M.; Yeo, R. (1996): Telling lives in science. Essays in scientific biography (M. Shortland, R. Yeo, eds.), Cambridge University Press, Cambridge: 1-44.

SöDERQVIST, T. (1996): Existential projects and existential choice in science: Science biography as an edifying genre. Telling lives in science. Essays in scientific biography (M. Shortland, R. Yeo, eds.), Cambridge University Press, Cambridge: 45-84. 